\title{
CULTURAL REVIVALISM OF MANGKUNEGARA VII AND THE ISLAMISM DISCOURSE IN THE EARLY $20^{\text {th }}$ CENTURY
}

\author{
Adi Putra Surya Wardhana, Titis Srimuda Pitana, and Susanto \\ Universitas Sebelas Maret Surakarta, Indonesia \\ E-mail: adiputra@student.uns.ac.id
}

\section{Abstract}

This article aims at studying Javanese cultural revivalism of Mangkunegara VII, its function, and meaning, within the context of the rise of Islamism in the early $20^{\text {th }}$ century. Mangkunegara VII was a Mangkunegaran ruler who actively participated in developing Javanese culture. When he was young, he was an essential figure in Budi Utomo, a movement organization that represented Javanese nationalism which was influenced by the complex relations between language awareness, colonialism, modernism, and Islamism. He was also involved in various Kejawen organizations. Using Michel Foucault's discourse theory, this paper argues that Javanese cultural revivalism is a Javanese nationalist success to overcome the excessive radicalism of Islamic discourse. When Islamism arose with their attacks against the abangan, he carried out counter-narratives through Javanese cultural organizations. As a ruler, he was successful in assuming legitimacy from the Mangkunegaran people as well as to influence the Dutch colonial government, and other Javanese nationalists as well.

Artikel ini bertujuan untuk mempelajari revivalisme kebudayaan Jawa yang dikonstruksi oleh Mangkunegara VII, bersama fungsi dan maknanya, di tengah-tengah pertumbuhan wacana Islamisme di awal abad 20. Mangkunegara VII adalah seorang penguasa Mangkunegaran yang berpartisipasi aktif dalam mengembangkan kebudayaan Jawa. Ketika ia 
muda, ia merupakan tokoh penting Budi Utomo, sebuah organisasi pergerakan yang merepresentasikan nasionlisme Jawa yang dipengaruhi oleh relasi yang kompleks antara Bahasa, kolonialisme, modernisme, dan Islamisme. Dia juga terlibat dalam sejumlah organisasi Kejawen. Menggunakan teori discourse Michael Foucault, artikel ini berargumen bahwa Revivalisme kebudayaan Jawa dimaknai sebagai keberhasilan Nasionalis Jawa dalam meredam radikalisme berlebihan dalam wacana Islamisme. Pada saat wacana Islamisme bangkit dengan menyerang kalangan abangan, ia melakukan kontra narasi melalui organisasiorganisasi kebudayaan Jawa. Sebagai penguasa, ia berhasil memperoleh legitimasi dari kawula Mangkunegaran, mempengaruhi pemerintah kolonial, orang Belanda, dan nasionalis Jawa lainnya.

Keywords: discourse; Islamism; Javanese culture; Mangkunegara VII; revivalism

Received: October 29, 2018; Accepted: May 16, 2019

\section{Introduction}

On Friday, October 12, 2018, a group of people destructed and disbanded the Sedekah Laut tradition in Bantul, Yogyakarta, on what they claimed as the call of religion (Sekelompok Orang Bubarkan Persiapan Tradisi Sedekah Laut di Bantul 2018; Polres Bantul Periksa Sembilan Orang Terkait Perusakan Properti Sedekah Laut 2018; Massa Bercadar Rusak Properti, Sedekah Laut Pantai Selatan Jogja Batal 2018). Based on the same sentiment, appropriating a natural disaster to deliver the message of religious purification, a poster written "do not float offerings because they can trigger Tsunami," appeared around the similar ritual site in Cilacap (Sekelompok Orang Bubarkan Persiapan Tradisi Sedekah Laut di Bantul 2018). In different place, there was also an obstruction incident of wayang kulit (shadow puppet) (Wayang Dilarang, Gus Ipul: Spanduk di Islam Dulu Enggak Ada 2017) followed by a challenge towards contemporary puppet performance show by a particular mass organization. They thought that the narrative presented in the performance went against religious teaching (Tak Suka Isi Cerita, Ormas Bubarkan Pertunjukan Wayang 2011). The same organization also forbade gamelan, claiming music as unlawful (Haramnya Musik dan Lagu 2011), as well as arguing that the sound of gamelan resembles that of a bell, while the bell was a medium of the devil (Nugroho 
2018). As all of those are of the Javanese cultures, such actions are considered hostile towards their tradition.

In the other side of Java, a particular organization demanded to demolish a statue of God in Tri Dharma Temple Kwan Sing Bio, Tuban, East Java for what was examined as the license problem (Simpang siur di Tuban: Apa yang terjadi dengan patung dewa tertinggi se-Asia Tenggara? 2017). There was a challenge towards a Buddha statue in Tanjung Balai, North Sumatra on a ground that the statue goes against the religious teaching adhered by the majority of the surrounding community (Penurunan patung Buddha di Tanjung Balai dianggap mengancam keberagaman 2017). Also, vandalism was observed in Purwakarta regency, West Java, and the list goes on, as reported by Tempo (Perusakan Patung di Purwakarta Bukan yang Pertama 2016). Finally, we cannot ignore an incident of religious blasphemy during the Jakarta 2017 Gubernatorial election, that brought one of the candidates, Basuki Tjahaja Purnama, to custody, which further led to the birth of institutionalization of the "212 movements" as a religious discourse to build political power. These actions raise a question, what is going on in Indonesian society?

The rise of religious purification is one of the phenomena emerging in the post-secular era of Indonesia. Post-secularism is a movement of reembracement of religious values which takes shapes as dissociation from the "Western" secularism (Hardiman 2016). Some symptoms of post-secularism include movements for reinforcement of contemporary religious literacy; a rising interest in religion; the struggle between religion, state and humanity; and the rapid conversion as well as the spread of transnational religion in the global scale. However, post-secularism does concern with religion as much as it does with power. Religious purification movements take advantage of democracy system to develop its social and political actions. Religious discourse is built in the political circle to gain power.

We would suggest that those incidents reflect the neo Islamic revivalism movement and post-Islamism. Neo Islamism is a movement that idealizes a comprehensive implementation of shari'a (kâffah) in a transnational context (Wibowo 2010; Kamal 2015; Murkilim 2017). The aim of neo Islamic revivalism is a radical change in the socio-political system towards an Islamic system (Rahmat 2005, 15). Meanwhile, post Islamism according to Bayat, through the Iranian case, is "expression in the idea of fusion between Islam (as a personalized faith) and individual freedom and 
choice; and post-Islamism is associated with the values of democracy and aspects of modernity" (Bayat 1996).

The struggle of the post-Islamist movement for their ideology involves a compromise between modernity and democracy. Additionally, Heryanto suggests, post-Islamism is also concerned with Islamic pop culture, which is marked by the emergence of pop preachers on television and Islamic films. Therefore, Post-Islamism was related to Islamic populism and the commodification of religion for the sake of power. In this lies some problems (Heryanto 2015, 50-51).

The rise of religious discourse became the conflict potential in society, particularly when it clashes with values established in the local culture. The upsurge of religious sentiment leads to the consideration that a culture contradicting to a particular religious' value is considered as a deviation. However, religious discourse was disseminated through popular culture. The masses who try to purify religion carry out verbal and physical pressure, which causes excessive religious radicalism. Besides, this discourse aims at formalizing Sharia law. This discourse offers an illusion or a beautiful imagination so that the masses were easily influenced to take action to defend religion. This discourse is, therefore, a repercussion of Pan Islamism in the past. This is the reason behind the necessity to study the history of the emergence of religious discourse.

Pan Islamism, developed in the late $19^{\text {th }}$ to the $20^{\text {th }}$ centuries, had a context of the struggle for freedom from colonialism. Their idea influenced some of the religious movements in Indonesia, such as Sarekat Islam (SI) through which the religious activist raised ideas of solidarity between Muslims. However, their movement became increasingly radical, marked by the establishment of a paramilitary wing, namely The Army of the Prophet Muhammad (Tentara Kanjeng Nabi Muhammad, TKNM). The terminology 'army' suggested their preparedness for excessive religious radicalism.

However, their movement did not only challenge the colonial ruler but also intersected with Javanese culture. Mangkunegara VII, a Mangkunegaran ruler, had an essential role in dealing with the rising religious discourse. During his time, the religious discourse had experienced a rapid increase. However, the religious discourse raised by SI has failed, while the cultural discourse has increased. Therefore, studying the clash of religious discourse against cultural discourse is quite essential.

This paper discusses the discourse of Javanese Mangkunegara VII cultural revivalism against the emerging religious discourse in the early 20th 
century. The problems to be examined are as follows: (1) what is the form of cultural revivalism of Mangkunegara VII? (2) how is the function of cultural revivalism of Mangkunegara VII against the Islamism discourse? and (3) what is the meaning of the revivalism of Javanese Culture among the Islamism discourse?

\section{Foucault's Discourse and Revivalism}

This writing uses several theories and concepts to explain the cultural revivalism of Mangkunegara VII against Islamism discourse. Michel Foucault defines discourse as a totality of place to rely on the distribution of the subject and its discontinuity. It is exteriority where the existence of specific site systems. It is a practice that forms relationships between elements that were previously developed. It is a set of utterances that can express the truth in the production of knowledge. Social practice always accompanies the dissemination of knowledge; therefore, it forms a power relation that lasts for a specified period. He also said discourse arises because of desire and power (Foucault 2012).

It is used to dissect the power of knowledge relations built by Mangkunegara VII through Javanese cultural revivalism which emerged along with the rise of discourse on Islamism promoted by the Sarekat Islam. It is also used to map discursive formations that lead to the emergence of Javanese Mangkunegara cultural revivalism VII.

The term 'revivalism' is rooted in 'revival' which means change or awakening. Despite the terminology developed from the history of the Christian tradition (Mudzakkir 2011), it does not merely relate to religious traditions. According to Siburian, modernization and rationalization are the cause of the birth of revivalism. According to him, modernization provides the urban middle class with socio-economic pressure, which further causes anxiety, to which revivalism comes promising the way to overcome such anxiety. The pressure of modernization influences the dynamics and existence of culture (Siburian 2007). According to Davidson and Henley, revivalism is closely related to the dynamics of culture, tradition, and custom caused by political, economic, and modernity pressures (Davidson and Henley 2007, 13-30). Thus, revivalism is an attempt to contemporaries the past, making it relevant to the present (Evers and Siddique 1993; Nurhakim 2011). This was used to explain socio-politics pressures that construct the cultural revivalism of Mangkunegara VII. This was also used to describe the Islamism discourse pressure to the Javanese nationalist. 


\section{Genealogy of Mangkunegara VII}

Mangkunegara VII, whose birth name was Suryo Suparto, was a ruler of the Kadipaten Mangkunegaran. Born on November 12, 1885 (also said August 15, 1885) to Mangkunegara V, he was entrusted by his father to his uncle, Kanjeng Pangeran Haryo Suyitno (then ascended to the throne entitled Mangkunegara VI). He did not know that his biological father was Mangkunegara V until his father died in 1896. He was appointed as a child by Mangkunegara VI. Not only did he study Javanese, but Suparto also studied European science at the Europeesche Lagere School (ELS) Surakarta in 1891 until 1901.

After the death of Suparto's father (Mangkunegara V), he wanted to continue his studies at Hoogere Burgerschool (HBS) Semarang, and to work as an employee in the Mangkunegaran office. Mangkunegara VI prohibited him from both, and Suparto was disappointed. He and his adoptive father had different visions. Instead, Mangkunegara VI wanted Suparto to learn to become a knight. He wanted Suparto to continue the army tradition in the Mangkunegaran family (Wiryawan 2011, 40-42).

Suparto went to Demak in 1905 to apply for a job to the Regent of Demak. He became an apprentice in the Demak Regency office, and further was appointed as a clerk to the regency secretary. While in Demak, he obtained the title Bendara Raden Mas Haryo (BRMH) Surya Suparto on May 2, 1904. He worked in Demak for four years. After that, he came back to Surakarta. He did not stay at home in Mangkunegaran at that time. Otherwise, he decided to travel to Kediri, where he disguised himself as a trader (Wiryawan 2011, 42-45). He improved his spirituality as he visited historical and sacred places. Then, he returned home and worked as the translator of Resident Van Wijk in Surakarta. He also became an activist at Boedi Oetomo (BO). Eventually, he went to Europe to study at Leiden University. He also attended military school in the Netherlands. After his return to Surakarta, he obtained the most important position in the BO.

The resignation of his foster father, Mangkunegara VI, from the throne in 1916 led to the conflict in the inheritance of the throne (Wasino 2014, 59-68). In the Mangkunegaran succession, the colonial government was always involved. According to Larson, the succession of Mangkunegaran was very complicated because the eldest son of the head of the breed could not necessarily replace his father. Suparto had to resign from $\mathrm{BO}$ so that he could be appointed as the head of the Mangkunegaran 
family (Larson 1990). Then, he ascended the throne to replace Mangkunegara VI in 1916.

He got the title of Kanjeng Gusti Pangeran Adipati Aria (KGPAA) Prangwedana VII. After he was old enough, he had the title of the KGPAA Mangkunegara VII. He ruled from 1916 to 1944. His reign was called the golden age of Mangkunegaran for his success in modernizing various fields in the region. Wasino suggests that Mangkunegara VII ruled when the Dutch East Indies experienced socio-political and socio-cultural changes. The former was marked by Dutch policy towards the colonies, the rise of nationalism, the growth of national organizations, and Sunan's (the ruler of Kasunanan Surakarta) attitude towards Mangkunegaran, while the latter was concerned with the acceptance of Javanese society towards Western understandings and ideas in Javanese society (Wasino 2014, 69). Since he was young, Mangkunegara VII had influenced by Javanese nationalism. He was also a witness of the conflict between Javanese nationalist and excessive radical Islamism.

\section{Clash of Islamism and Javanese Nationalism Discourse}

Mangkunegara VII ruled when Islamism discourse gaining increasing popularity. Having been concerned more with the Javanese nationalism, Mangkunegara VII built a cultural discourse. At one point, the two discourses clashed. This section discusses the clash between the two. To begin with, the following will firstly elaborate on the rise of Islamism discourse.

Islamic reform has the idea of religious puritanism. The movement was strongly connected to the Wahhâbî movement, which had emerged in the Middle East began since the $18^{\text {th }}$ century. At the end of the $17^{\text {th }}$ century to the beginning of the $19^{\text {th }}$ century, this movement expanded into West Sumatera that started the Paderi War (Margana ed. 2017, 43). The Paderi War increased the spirit of Islamic revivalism. Their basic idea was to purify Islamic teachings from pre-Islamic customs (Ricklefs 2010, 304-5).

On the other sides of Muslim societies, Pan Islamism movement also emerged. Developed by Jamaluddin al-Afghani, influenced-movements in the Dutch East Indies, the idea of Pan Islamism was to unite the entire Islamic world under one political power, that is the religion-based power or the Khilâfah Islâmiyah (Toriquddin 2011). This movement was unique because it combined religious orthodoxy with modernity brought by European. Later on, this movement connected with Wahhbism. 
In Indonesia, one of the organizations working under the influence of Pan Islamism was Sarekat Islam (SI). This organization was originated from a Ronda association called Rekso Roemekso, which was founded by Haji Samanhoedi. Later, they claimed to be part of the Sarekat Dagang Islamijah (SDI) raised by Tirtoadhisoerjo for a legal problem. In 1912, this organization was better known as the independent Sarekat Islam (Shiraishi 1997, 55-58). Under the leadership of Tjokroaminoto, this organization proliferated.

In its development, Tjokro became radical. Tjokroaminoto, Agus Salim, and Abdul Moeis stated that the party's ideology was in line with the Pan Islamism movement in the Middle East (Nugroho 2013; Somad 2015). Through the Al-Islam Congress in Cirebon on October 31 - November 2, 1922, the Sarekat Islam supported the unity of the Islamic community based on Pan Islamism (Shiraishi 1997, 326). Along with its hostility to colonialism, Sarikat Islam also challenged the abangan who preached Javanese nationalism. This was because they were considered as an impure Islam.

This attack disturbed the Javanese nationalists who were active in developing the Javanese culture. One of the notable names among the Javanese nationalist was Mangkunegara VII. This clash originated from a controversial article in the mass media.

On January 1918, Martodharsono, chief editor of newspaper Djawi Hiswara published a controversial article entitled "Pertjakapan antara Marto dan Djojo" (Dialogue between Marto and Djojo). Djojodikoro, an editorial staff, wrote the article. SI, in which Martodharsono was a prominent figure, felt offended by the article. However, personally, Martodharsono were closer to Javanese nationalist groups and Javanese royal aristocracy (Rahzen et al. 2007, 19). He studied invulnerable and mysticism. The content of the article that became a controversy also contained Javanese sciences. Therefore, this article became the lighter contradiction between the putihan and abangan groups. The article mentions,

"Saja boekan goeroe, tjoemah bertjerita atau memberi nasehat, kebetoelan sekarang ada waktoenja. Maka baiklah sekarang sadja. Adapon fatsal (selamatan) hoendjoek makanan itoe tidak perloe pakai nasi woedoek dengan ajam tjengoek brendel. Sebab Gusti Kandjeng Nabi Rasoel itoe minoem tjioe A.V.H. dan minoem madat, kadang kle'let djoega soeka. Perloe apakah mentjari barang jang tidak ada. Maskipon ada banjak nasi woedoek, kalau tidak ada tjioe dan tjandoe tentoelah pajah sekali" (Rahzen et al. 2007, 16). 
"I am not a teacher; [I] just tell a story or give advice. It is only in time now, so it is okay now. As for the article (salvation), the food dish does not need to use nasi uduk with broiled chicken. Because of His Highness the Prophet of the Apostles drinks ciu (wine) A.V.H and smokes opium; sometimes he likes klelet (residue of opium) too. Why do [you] need for items that do not exist[?] Even though there is a lot of nasi uduk, if there is no ciu (wine) and opium, it would be horrible."

At the end of the article, Martodharsono added a note, "this article is inappropriate to be published in a newspaper because it will hurt those who cannot admit it." Initially, the article did not trigger a polemic until Tjokro had made it a problem. Muslims suddenly ignited emotion. Tjokro exploited this situation to build a discourse that the colonial government ignored Islam (Shiraishi 1997, 144; Rizal 2012). He immediately gathered santri and Arab merchants, collected money, and mobilized SI branches which were not well-maintained with the spirit of defending religion. He demanded Sunan and the colonial government to capture Martodharsono and Djojodikoro. Action to protect Islam and the prophet was held by all sympathizers and members of the SI (Shiraishi 1997, 144; Juma' 2018, 379). This incident was used to revive the Sarekat Islam because it was down in prestige at the time.

A clarification was released immediately by Martodharsono in Djawi Hiswara, February 4, 1918, “...Dalam percakapan itu, bukan nabi kita S.A.W., Kandjeng Nabi Mohammad Rasul Allah, tetapi rasulnja orang masing-masing. Jadi, siapa yang bercakap, ialah yang mempercayainya..." (In that conversation, it was not our prophet S.A.W., His Highness Prophet Mohammad, Apostle of Allah, but the apostle of each person in conversation instead. So, whoever speaks is the one who believes it). He also added that the article was an example of a wrong article. However, this clarification did not reduce the anger of the masses. Tjokro formed a paramilitary wing, namely the Army of the Prophet Mohammad/Tentara Kanjeng Nabi Mohammad (TKNM) in Surabaya in February 1918. The aim was to "defend the honor of Islam, the Prophet, and the Muslims" (Shiraishi 1997, 144). The use of the word army shows the militancy of the martial arts warriors. For the first time, their militancy was organized to attack groups accused of being secular or abangan (Rizal 2012). Ricklefs narrates this conflict as follows: 
"In 1917, the Comite voor het Javaansch Nationalism, the committee for Javanese nationalism, was established; this committee was active in 1918 when it started to publish monthly Wederopbouw, "reconstruction." The main guiding force behind this movement was the Kadipaten Mangkunegaran, specifically Mangkunegara VII (1916-44). Javanese nationalism and Islamic renewal clashed when a paper appeared in a newspaper in Surakarta, Djawi Hisworo, "Java king," in January 1918 which slandered the Prophet Muhammad as a drunkard and opium smoker. Muslims incensed; in February, they formed a committee called Tentara Kangjeng Nabi Muhammad. Comite voor het Javaansch Nationalisme issued a pamphlet condemning religious fanaticism. Although these people also denounced the Djawi Hiswara's article style, Islam, as reformers were now teaching it, seemed to them as an unwelcome foreign import" (Ricklefs 2010, 379-80).

The above narrative illustrates that the poorly written article was a trigger for the clash between putihan and abangan, between TKNM led by Tjokro and Comite voor het Javaansch Nationalisme (CJN) which was protected and inspired by Mangkunegara VII. TKNM protest was responded by CJN, denouncing it as an excessive religious fanatism and an unwelcomed foreign import. It is just fair to assume that Mangkunegara VII also believed the same attitude because he was the intellectual actor behind CJN. The CJN considered that the articles of Djojodikoro and Marthodarsono introduced Javanese sciences to the public. The attack on Djojo and Marto was considered an act that did not respect Javanese sciences. Therefore, the CJN movement represents the criticism from the Javanese nationalist group to Islamism discourse. The incident was exploited by TKNM to a fundraising movement, aiming at contributing to the reinforcing of Muslims community. On February 24, the campaigns were conducted simultaneously in forty-two places throughout Java and parts of Sumatra, reported to had been attended by 150.000 people. Significant funds were collected by TKNM, as many as ten thousand guilders. This means the Islamic Defense Act succeeded in uniting SI.

After the anti-Martodharsono and anti-Djawi Hiswara movements, TKNM moved to the anti-Christian missionary movement. Fighting Christian missionary was considered the true Islam in TKNM propaganda. They got support from the Putihan and Arabs communities. However, the discourse that was built, the propaganda disseminated, and the campaign conducted against the secularists and the Christian missionaries did not last 
very long. Voices of dissatisfaction with the actions of TKNM emerged. People started to say that TKNM was no more than fundraising and sending telegrams of protest to Sunan and the Governor General Tjokro was accused of corruption. The progressive group under Haji Misbach immediately took on the role after TKNM withered (Shiraishi 1997, 177 86).

\section{Javanese Cultural Revivalism of Mangkunegara VII}

The $20^{\text {th }}$ century was a period full of social, economic, political, and cultural changes. During this time, Suryo Suparto (Mangkunegara VII) became an activist. He was an active member of Boedi Oetomo (BO) since he became a translator of Resident van Wijk. He was also an editorial assistant in a newspaper using Javanese, Dharma Kanda in Surakarta. After that, he traveled to the Netherlands. During the journey, the prince realized the fate of his people, who were left behind by other nations. His mission was told in a diary titled "Sêrat Cariyos Kêkesahan Saking Tanah Jawi Dhatêng Nagari Walandi." His wandering story was also recorded by the author of Pusaka Jawi (August-September, 1924), as follows:

"...Radèn Mas Arya Suryasuparta, juru basa Jawi ing Surakarta, kalêrês putra kaponakan dalêm Kangiêng Gusti Pangeran Adipati Arya Mangkunagara VI. Tindakipun prayagung kêkalih punika namung nuruti karsanipun ingkang sampun lami sinimpên wontên salêbêting panggalih, badhe nyatakakên kawontênanipun ing tanah Europa, gêsangipun têtiyang Europa langkunglangkung ing Nèdêrlan. Kajawi punika Radèn Mas Arya Suryasuparta sumêdya anjêmbarakên pangawikan lan anggêgulang kawruh basa Indiya, langkung. langkung basa Jawi, sarana pratikêl ingkang prayogi sarta urut mindhakmindhakipun, supados sagêda sampurna ing basa wau" (Pusaka Jawi AugustSeptember, 1924).

"Raden Mas Arya Suryasuparta, a Javanese linguist in Surakarta, was Kanjeng Gusti Pangeran Adipati Arya Mangkunegara VI's adoptive son and nephew. The departures of both nobles were to follow the long-held will in the heart to see the reality in European, the lives of Europeans in the Netherlands. Therefore, Raden Mas Arya Suryasuparta had a plan to expand the knowledge and teaching of Indian (Indonesia/ Dutch East Indies) grammar, especially Javanese, as a kind and orderly way to improve it so that he can be perfect in language." 
The quote illustrates Suparto's departure in Europe as a hope that comes true. He went to Europe to study Indian (Indonesian) language, especially Javanese. He believed that modern European academic culture could enhance knowledge in the literature and language. He also wanted to see with his own eyes the Europeans life in Europe. He wanted to see the European modernity. This shows that Suparto was influenced by modern European knowledge. Presumably, this trip triggered the prince to build a discourse on the revival of Javanese culture so that the Javanese people could be more advanced and not left behind with the Europeans.

He wanted to realize the memories of the glory of the Jenggala Kingdom during Prabu Suryawasesa's time (Panji Asmarabangun) which depicted "arum ngebekti sa Nuswantara" (famous throughout the Nusantara) as well as stories in Javanese texts and Javanese folklore. After returning to the Dutch East Indies (Nusantara/Indonesia), he was very active in BO and later appointed as chairman in 1915 (Wasino 2014, 64-68).

The Mangkunegara VII became an intellectual actor behind Javanese nationalism movement. His Javanese nationalism ideology was represented in his involvement in the Javanese youth organization, Tri Koro Dharmo and Javaansche Padvinders Organisatie (Java Scout Organization) in 1916. He was also the man behind the Comite voor het Javaansch Nationalisme (CJN) which was established in 1917; the Prangwedana escorted the movement.

To disseminate cultural discourse, CJN needs media. In 1918, CJN published the monthly Wederopbouw (reconstruction), which became the media to show cultural discourse (Larson 1990, 104-08; Ricklefs 2010, 379 80). Also, other media were also used to disseminate cultural discourse. On January 1918, the Djawi Hiswara newspaper that represents the Javanese nationalism published controversial articles (Shiraishi 1997, 144; Rahzen et al. 2007, 16-19). CJN protected the writer of the article from the pressure from TKNM and distributed pamphlets condemning religious fanaticism (Ricklefs 2010, 380). As a result, TKNM was angry at the CJN's response and reinforced their movement. In July 1918, the First Congress of the Development of Javanese Culture initiated by Prangwedana and CJN was held. Tjokro boycotted the Congress, Oetoesan Hindia, the media owned by SI attacked the Congress (Larson 1990, 155-56). This incident shows the contestation between Islamism and Kejawen during that period.

Niwandhono suggests that this incident was one of the influences of the growing sentiment of the Javanese nationalist who considered the post- 
arrival of Islam a setback, while the period of Indian-Javanese civilization to the glory of Majapahit was the honorable ideal Javanese civilization (Niwandhono 2017). This is a form of cultural politics. Encountering the increase of excessive religious fanaticism on politics, Mangkunegara VII chose to use the path of strengthening Javanese culture, i.e., the Javanese cultural revivalism discourse. He used the knowledge he had obtained from his trip to Europe to disseminate this discourse. He was concerned that the rise of religious fanaticism challenged Javanese culture. He was also worried about Javanese culture, which started to decline in young people.

Mangkunegara VII began his work through developing Javanese as a mother tongue (Ferdiyanah 2017). That is because he saw language as a tool and a form of consciousness. Language is a medium of communication between people to explain and understand each other. Language is a means to build collective awareness and medium for expressing the will and the desire in human consciousness (Pitana 2014, 40-47). This means that he wanted to create a collective awareness about the urgency of Javanese. Thus, his motivation was to gain influence among the Javanese people, even Europeans in the Dutch East Indies through the development of Javanese Language. Then, Mangkunegara VII initiated the establishment of Java Instituut (Institute of Java).

This was an organization that works to develop language, literature, and Javanese, Madurese, Sundanese, and Balinese culture. Javanese and Dutch people managed this. In the beginning, this institution had around 50 members, half of whom were European. The protector of this institution was the Governor General, Prangwedana was the honorary chairman, and RA Dr. Hoesein Djajadiningrat, his son-in-law, was the daily chairman. On the one hand, this also shows the form of the hegemony of Javanese culture towards Europeans.

On the other hand, this also shows that they wanted to rule Javanese culture, especially in terms of academics to easily control the Javanese community. Control here means the colonial government could take policy based on suggestions from experts on Java. Nevertheless, Mangkunegara VII cleverly used his discourse to obtain a prominent position among European Javanology experts.

Mangkunegaran showed a vital role in this institution when he had the opportunity to host the $10^{\text {th }}$ anniversary of the Java Institute on December 27 to 29, 1929 at Kepatihan Mangkunegaran (De Indische Courant, September 26, 1929). This institution also succeeded in making 
the government participate in providing financial assistance. For example, there was assistance in establishing a craft school and renovating a museum in Yogyakarta in March 1941 (Soerabaiasch Handelsblad, March 3, 1941).

Mangkunegara VII was influenced by the thought of associations, which was central to the Theosophy discussions. He was a member of the Theosophical organization (Nugraha 2011, 80). Theosophy was an organization that aims at forming a universal brotherhood of humanity, regardless of race, belief, gender, caste, and skin color. This organization studied the comparison of religion, philosophy, and science. Then, another goal was to investigate the laws of nature that cannot yet be explained and the hidden energy in humans (Nugraha 2011, 7). Therefore, the leadership built by Mangkunegara VII sought to bridge Western (modern) thinking with East (Traditional). Java Instituut succeeded in involving prominent Javanese aristocratic figures to develop Javanese culture in an organization sponsored by Mangkunegaran.

Larson suggests that the prince Koesoemojoedo, Sunan's favorite son became chairman of the Contact Committee in April 1925, a realization of contact between Java Instituut and other groups in Surakarta. Although the relationship between Sunan and Prangwedana was terrible enough, the prince could work together to promote Javanese culture. Prangwedana had the idea of forming the Vorstenlanden (Land of the Prince) federation as an attempt to express legitimacy among the kings in Java. He wanted to show that his position was the same as Sunan's. This discourse was also used to counter the discourse of religious and communist radicalism, which was mixed with political interests. He used the art of pedhalangan and karawitan to gain sympathy from the people (Larson 1990, 107).

He was very interested in the world of puppetry. He was also very enthusiastic about the stories of Panji-Raden Damarwulan to he compiled a text which tells the story of the wayang krucil (Mangkunegara VII, 1935). The performing arts that use this story also gained development, namely Langendriyan. He developed the form of the Langendriyan performance consisting of seven people, so it was called Langendriyan Pitu (Widyastutieningrum 2006, 7). The seven players play the role of Damarwulan, Sabdopalon, Noyogenggong (Melik), Menakjinggo, Dayun, Wahita, dan Puyengan (Sumosutargio 1985). Presumably, Mangkunegara VII liked Majapahit background stories. This indicates that he was 
fascinated by the majestic archipelago of Majapahit as well as other Javanese nationalists.

He also developed the art of waranggana (traditional Javanese singer), opened art courses to the broader community, and presented wayang wong (classical Javanese opera) outside the palace walls (Wasino 2014, 211-12). Some of the sacred and palace-centric palace arts were displayed to the general public. The puppet was very popular to Javanese because it contains deep philosophical meanings. Meanwhile, karawitan (Javanese Traditional Orchestra) is not only harmonious and beautiful traditional music but also includes the meaning of life in each of the tunings. Similarly, dance is not only pleasing to watch but also consists of a philosophical sense in every move and story. The people could enjoy palace art that was previously limited by the palace walls.

The influence of modernity from European culture did not make it far from Javanese culture. He did not reject modernity as a whole. He also did not deny any updates to Javanese culture. The renewal was done to deal with the times. He realized that Javanese culture was basically liquid. This reality is described by one of the authors in Pusaka Jawi as follows,

"Kangjêng gusti botên pisan-pisan karsa ethok-ethok dados Walandi, sanajan sangêt rêmênipun dhatêng kawruhipun sae tiyang Eropah, sok ugi botên makèwêdi katiru, lan sanajan panjênêngan dalêm punika sampun lanji sangêt kêmpalan kalihan bôngsa Eropah ingkang sampun apangajaran. Sanajan kangjêng gusti rêmên sangêt dhatêng adat Jawi ingkang sae-sae lan prayogi, ewadene botên wêgah lan kêncêng niyat ngicali utawi nolak ingkang botên pêrlu-pêrlu, ingkang limrahe tuwuhipun saking kamunduraning têtiyang Jawi salêbêtipun kalih utawi tigang atus taun sapriki andadosakên karisakan" (Pusaka Jawi, August-September, 1924).

"Your Majesty never pretended to be a Dutchman even though he was very friendly with Europeans, nor was he afraid to be affected, and even though His Majesty had long been friends with educated Europeans. Although your Majesty was very fond of good and noble Javanese customs, he was willing and willing to eliminate or reject the unnecessary ones who generally inherited the decline of the Javanese in two or three hundred years until now which caused damage."

In the above passage, the author explains that Mangkunegara VII was a figure who was close to Europeans. However, he successfully preserved his Javanese culture and identity. In that respect, he was open to 
changes that could develop and improve Javanese culture under the changing times. It means that he did a revival of Javanese culture.

He used modernity to disseminate Javanese culture. One of them was utilizing radio technology. First of all, he recorded the gamelan music into the vinyl record for dissemination. Later, he bought radio transmitter to spread the traditional art of Mangkunegaran Palace. After making technological improvements, he pioneered the establishment of Solosche Radio Vereeniging (SRV) radio in 1933. Through radio broadcasts, people from outside the walls of the palace could enjoy and listen to the unique art. SRV broadcasts were not just arts and culture, but also Islamic Studies (Wiryawan 2011, 95-138). This was why SRV broadcasts were able to get an enormous influence. The extent of the impact of SRV in society was one proof of the success of the Mangkunegara VII Javanese Cultural revivalism discourse.

\section{The Function of Javanese Cultural Revivalism Discourse}

The form of the discourse built by Mangkunegara VII-included initiating the establishment of an institution engaged in the development of Javanese culture, opening traditional art courses, and presenting a portion of the palace's sacred arts to the public-had some functions.

First of all, it amplified the Javanese nationalism. Through the discourse of Javanese cultural revivalism, Javanese nationalists could imagine the glory of the Hindu-Buddhist civilization. That was why Mangkunegara VII liked to show Langendriyan, which tells the story of the Majapahit period. Through this discourse, Javanese nationalists such as Mangkunegara VII disseminated ideas about the Java adiluhung. According to Fakih, Java adiluhung (honorable) was an attempt to revive and regenerate Javanese culture to make it the basis of the myth of a new nationality (Fakih 2014). This means Java adiluhung became a critical speech and idea in the Javanese Cultural revivalism discourse to strengthen Javanese nationalism.

Secondly, this had a function to counteract Islamism discourse. The Islamism discourse that attacked the abangan or secularist indeed troubled Javanese nationalists. The European Orientalists views the decline of Javanese civilization was due to Islamization (Fakih 2014). The egalitarian character pursued by Islamic political revival (Islamism) was considered a foreign element that could threaten the traditional feudal order (Niwandhono 2017). This is the reason behind the rejection of Soetatmo Soeriokoesoemo, a Paku Alaman nobleman and a typical Javanese 
nationalist, against Islamism. He also rejected East Indies multi-ethnic nationalism, European liberal democracy, and Marxism because he believed on an autocratic state like the pre-colonial Javanese political order (Niwandhono 2014).

However, this does not mean that they had an anti-Islam sentiment. What they pursued was harmonizing Islam and Javanese culture. They had practiced a combination of Islam and Javanese culture with what was referred to Kejawen, as practiced in the Mangkunegaran. The harmony between Islam and Javanese culture is represented by the daily story of Mangkunegara VII in "Riwayat Hidup Sri Mangkunegoro VII."

On Wednesday, Thursday night, every gate of the Palace is cleaned and decorated with electric lights to make it looks bright. On Wednesday, Thursday night, in the Palace, a Pengajian (recitation) was held by the santri, including at the Pura's Mosque, with the intention of begging for forgiveness of all of Sri Paduka's sins and commending praise and gratitude to God Almighty, so that Sri Paduka was always blessed with health and longevity. Then, His territory will still be in peaceful, including all the residents of the area he leads to be always safe and prosperous (Soepardi 1993, 31).

The above narrative illustrates that Mangkunegaran VII held some routine religious activities as a form of worship to God. The context of the manuscript is the 32nd anniversary of the Prangwedana (Mangkunegara VII). The next action in the script was the performance of karawitan art which presented gendhing monggang and kodok ngorek. It shows that religious activities could be carried out; Javanese cultural activities could also run. SRV as a radio founded by Mangkunegara VII had Islamic study programs and relayed Friday Prayer broadcasts as well. This was to attract Muslim sympathies. The SRV broadcast also consists of a discourse on the indigenization of Islam. All of these mean that Mangkunegara VII was a religious and cultured leader, so those religious and cultural activities were not abandoned. He wanted to show Javanese and Islamic culture could be harmonious so that life could be more peaceful than the extremity, which causes discord. This also proves that he was not an anti-Islam. Although according to TKNM, Javanese nationalists were abangan or secular groups that were not true Muslims, he is a Muslim. This is the function of this discourse in the face of Islamism. 
The next function of the Javanese Cultural revivalism discourse was to disseminate the influence of Mangkunegara VII. Influence is the core of power (Marbun 1996). This means influence is the power that raises awareness, unconsciousness, belief, or behavior of others and many people to follow the will of the influencer. In this case, he built an influence so that they were constituted as subjects in the Javanese Cultural revivalism discourse. Thus, Mangkunegara VII could be called as an influencer. Influence has a relationship with the formation of charisma.

According to Kamus Besar Bahasa Indonesia, charisma is an extraordinary ability or quality of individual personality possessed by a person in terms of leadership, giving rise to admiration and admiration for society (Pusat Bahasa 2013, 627). According to Weber, charisma is obtained by individuals because it has extraordinary traits, blessings, and gifts in the eyes of those around them (Gerth and Mills eds. 1946, 78-79). Through the discourse, Mangkunegara VII gained charisma as a protector and developer of Javanese culture.

He became a highly respected figure as a founder of Java-Instituut. Then, he was appointed as an eerevoorzitter (Honorary Chairman) of the organization. He was able to attract sympathy from the colonial government, European intellectuals, indigenous nobles, and Javanese people to be involved in Javanese cultural development activities. Then, he was known as a charismatic Javanese leader. He was also trusted as a member of the Volksraad (House of Representatives) from 1918 to 1921. Therefore, the last function of this discourse was to obtain charisma.

\section{The Meaning of Javanese Cultural Revivalism Discourse}

Some orientalists interpret Javanese cultural revivalism as a rival discourse on Islamic political revival or Pan-Islamism, on which ground they also supported the dissemination of this discourse. This discourse is also interpreted as the construction of knowledge built by Javanese nationalists to realize the ideal of the Javanese state, namely a country founded by Javanese communities (Staat van Javaansche Gemeenschappen) (Niwandhono 2014). Therefore, Javanese nationalists were very active in campaigns, actions, and movements in the development of Javanese culture.

Various types of the discourse which were manifested in the actions of developing Javanese culture reflects the meaning of celebrating harmony in life. Cultural unity became a way to restrain the pace of extremism that utilizes religious discourse. Philosophical values in Javanese traditional art 
needed to be disseminated to create a more harmonious life in interpreting the differences.

The Javanese quickly absorbed this discourse at that time. It is within this context that Mangkunegara VII could obtain charisma from the subjects. The success of the discourse was illustrated in the passage of the following article:

"Saupami botên angsal bantu saking Kangjêng Gusti Prangwadana, saèstu botên wontên konggrès voor Javaansche Cultuur-ontwikkeling, inggih punika ingkang kawontênakên kala taun 1918 lan ing taun 1919 ing Sala, botên wontên konggrès Taal, Land-en Volkenkunde, Java Instituut sampun masthi botên badhe wontên. Kajawi punika kathah lêlabêtan utawi ingkang tuwuhipun saking pangudi dalêm" (Pusaka Jawi, 1924).

"If there was no assistance from Kanjeng Gusti Prangwedana (MN VII), the congress voor Javaansche Cultuur-ontwikkeling held in 1918 and 1919 in Sala, the Taal- Congress, Land-en Volkenkunde, Java Instituut would not be held. Therefore, there were many services or results from his works."

The above passage shows the significant meaning of the works of Mangkunegara VII in developing Javanese culture. Additionally, it also indicates that the author was influenced by the Javanese cultural revivalism discourse of Mangkunegara VII. Besides, he was known as an unpretentious, modernist, and Javanese cultural activist. Thus, this discourse was interpreted as the success of the Mangkunegara VII strategy to influence the subjects consisting of the colonial government, European intellectuals, nobles, and Javanese people.

Besides, this discourse was also interpreted as a rejection of all kinds of extremism by glorifying the adiluhung Java. Javanese cultural revivalism conveyed messages to turn back excessive radicalism. Thus, Mangkunegara VII carried a message of peace through cultural revivalism discourse. There was a production of knowledge of the tremendous Javanese values that were able to provide peace in life. This needs to be studied by the present generation. In other words; it is not easily broken down by excessive radicalism discourses. Thus, the community can be wiser in addressing a problem concerning culture and religion. 


\section{Conclusion}

In the present era, the wave of ideological battles and discourses influenced by post secularism has increased rapidly. The phenomenon of Neo Islamic Revivalism and Post Islamism emerged. Identity politics, over religious fanaticism, and religious discourse make use of democracy for specific purposes. Local culture is displaced by strengthening religious discourse. Religious purification circles challenge Javanese art because it is considered heretical. A similar phenomenon occurred in the colonial period when the wave of Pan Islamism influenced the organization of national movements. At that time, a wave of religious fanaticism increased rapidly when Djawi Hiswara published a controversial article. Therefore, Mangkunegara VII chose to use discourse on Javanese cultural revivalism to deal with Pan Islamism's discourse.

\section{References}

Bayat, Asef. 1996. "The coming of a post-Islamist Society." Critique: Critical Middle Eastern Studies 5(9): 43-52.

Davidson, Jamie S., and David Henley, eds. 2007. The Revival of Tradition in Indonesian Politics The deployment of Adat from Colonialism to Indigenism. Oxon. New York: Routledge.

De Indische Courant. 1929. 26 September. delpher.nl (September 15, 2018).

Evers, Hans Dieter, and Sharon Siddique. 1993. "Religious Revivalism in Southeast Asia: An Introduction." Sojourn: Journal of Social Issues in Southeast Asia 8(1): 1-10.

Fakih, Farabi. 2014. "Akar-akar Kanan daripada Nasionalisme Indonesia: Nasionalisme Jawa dalam konteks kesejarahannya." Lembaran Sejarah 11(1): 37-49.

DOI: https://doi.org/10.22146/lembaran-sejarah.23782

Ferdiyanah, Serly Nur Hidaya. 2017. "Peranan Mangkunegara VII dalam Mengembangkan Kebudayaan Jawa 1918-1942.” Avatara: e-Journal Pendidikan Sejarah 5(2): 309-27.

Foucault. Michel. 2012. Arkeologi Pengetahuan. Trans. Inyiak Ridwan Muzir. Yogyakarta: IRCiSoD. 
"Haramnya Musik dan Lagu." 2011. http://asysyariah.com/haramnyamusik-dan-lagu/ (October 15, 2018).

Hardiman, F. Budi. 2016. “Post-Sekuralisme.” Kompas. June 16.

Heryanto, Ariel. 2015. Identitas dan Kenikmatan: Politik Budaya Layar Indonesia. Jakarta: Kepustakaan Populer Gramedia.

Kamal, Ali Mustofa. 2015. "Menimbang Signifikansi Demokrasi Dalam Perspektif Al-Qur'an.” Ulul Albab: Jurnal Studi Islam 16(1): 45-61.

DOI: http://dx.doi.org/10.18860/ua.v16i1.2783

Juma'. 2018. "Kontinuitas dan Transformasi Penistaan Agama: Gerakan Sosial Islam PraKemerdekaan.” Jurnal Lektur Keagamaan 16(2): $372-$ 94.

DOI: http://dx.doi.org/10.31291/jlk.v16i2.568

Larson, George D. 1990. Masa Menjelang Revolusi. Yogyakarta: Gadjah Mada University Press.

Mangkunegara VII. 1935. Langendriya, Pakem Pedhalangan Ringgit Krucil. Betawi: Balai Pustaka.

Margana, Sri, ed. 2017. Agama dan Negara di Indonesia Pergulatan Pemikiran dan Ketokohan. Yogyakarta: Ombak.

"Massa Bercadar Rusak Properti, Sedekah Laut Pantai Selatan Jogja Batal." 2018.https://news.solopos.com/read/20181013/496/945723/mass a-bercadar-rusak-properti-sedekah-laut-pantai-selatan-jogja-batal (October 13, 2018).

Mudzakkir, Amin. 2011. "Revivalisme Masyarakat Adat dalam Politik Lokal di Indonesia Pasca-Soeharto: Studi Kasus Komunitas Kampung Naga, Tasikmalaya, Jawa Barat.” Jurnal Masyarakat $\mathcal{E}$ Budaya 13(1): 167-84.

Murkilim, Murkilim. 2017. "New Revivalisme Islam.” Nuansa: Jurnal Studi Islam dan Kemasyarakatan 10(2): 164-70.

Niwandhono, Pradhipto. 2017. "Nasionalisme Kejawen: Dahulu dan Sekarang."https://www.kompasiana.com/wandha/59c1167f2bb4bf 045a4fbc62/nasionalisme-kejawen-dahulu-dan-sekarang (October 23, 2018). 
Niwandhono, Pradhipto. 2014. "Gerakan Teosofi dan Pengaruhnya Terhadap Kaum Priyayi Nasionalis Jawa 1912-1926.” Lembaran Sejarah 11(1): 25-36.

DOI: https://doi.org/10.22146/lembaran-sejarah.23781

Nugraha, Iskandar P. 2011. Teosofi, Nasionalisme, EE Elite Modern Indonesia. Jakarta: Komunitas Bambu.

Nugroho, Anjar. 2013. "Wacana Islam dan Negara Era Pra-Kemerdekaan: Pergulatan Ideologis Kelompok Islam dan Nasionalis Sekuler." Afkaruna: Indonesian Interdiciplinary Journal of Islamic Studies 9(2): $129-$ 47.

Nugroho, Garin. 2018. Hubungan Agama Islam dengan Enviromen Gamelan Dilema Tawar Menawar sebagai Proses Berbangsa. International Gamelan Festival, August 9-16.

Nurhakim, Moh. 2011. "Gerakan Revivalisme Islam dan Wacana Penerapan Syariah di Indonesia: Telaah Pengalaman PKS dan Salafi." Ulul Albab: Jurnal Studi Islam 12(1): 1-14.

DOI: http://dx.doi.org/10.18860/ua.v0i0.2393

"Penurunan patung Buddha di Tanjung Balai dianggap mengancam keberagaman." 2017 https://www.bbc.com/indonesia/indonesia37814837 (October 15, 2018).

"Perusakan Patung di Purwakarta Bukan yang Pertama." 2016. https://nasional.tempo.co/read/743993/perusakan-patung-dipurwakarta-bukan-yang-pertama (October 13, 2018).

Pitana, Titis Srimuda. 2014. Teori Sosial Kritis: Metode dan Aplikasinya. Purwokerto: STAIN Press.

"Polres Bantul Periksa Sembilan Orang Terkait Perusakan Properti Sedekah Laut."2018.http://www.tribunnews.com/regional/2018/10/13/pol res-bantul-periksa-sembilan-orang-terkait-perusakan-properti-sedekahlaut. (October 13, 2018).

Pusaka Jawi. August -September, 1924. sastra.org (April 12, 2015).

Pusat Bahasa. 2013. Kamus Besar Bahasa Indonesia. Jakarta Gramedia Pustaka Utama. 
Rahmat, Imdadun. 2005. Arus Baru Islam Radikal: Transmisi Revivalisme Islam Timur Tengah ke Indonesia. Jakarta: Erlangga.

Rahzen, Taufik. et. al. 2007. Tanah Air Bahasa Seratus Jejak Pers Indonesia. Jakarta: I:BOEKOE.

Ricklefs, M. C. 2010. Sejarah Indonesia Modern 1200-2008. Jakarta: Serambi.

Rizal, J.J. 2012. "TKNM \& Sejarah Gerakan Pembela Islam.” Koran SINDO. May 8.

"Sekelompok Orang Bubarkan Persiapan Tradisi Sedekah Laut di Bantul." 2018.https://news.detik.com/berita-jawa-tengah/d-

4254917/sekelompok-orang-bubarkan-persiapan-tradisi-sedekah-lautdi-bantul (October 13, 2018).

Shiraishi, Takashi. 1997. Zaman Bergerak: Radikalisme Rakyat di Jawa 1912. 1926. Jakarta: Pustaka Utama Grafiti.

Siburian, Esra Parmian Talenta. 2007. "Perjalanan Hidup dan Upaya Membangkitkan Kembali Seni Opera Batak Tilhang Serindo." Harmonia: Journal of Arts Research and Education 8(3).

DOI: https://doi.org/10.15294/harmonia.v8i3.776

"Simpang siur di Tuban: Apa yang terjadi dengan patung dewa tertinggi seAsia Tenggara?.” 2017. https://www.bbc.com/indonesia/trensosial40790781 (October 15, 2018).

Soerabaiasch Handelsblaad. 1941. March 3. delpher.nl (September 15, 2018).

Soepardi. 1993. Riwayat Hidup Sri Mangkunagoro VII sampai usia 32 Tahun. Surakarta: Rekso Pustoko.

Somad, Abdul. 2015. "Pemikiran dan Pergerakan Pan Islamisme di Indonesia pada Awal Abad ke-20: Studi Tentang Pergerakan Khilafah Kongres Al-Islam Hindia." Jurnal Candrasangkala 1(1).

Sumosutargio, Tarwo. 1985. Langendriyan Mandraswara dari Puro Mangkunegaran: Riwayat dan Perkembangannya. Surakarta: Rekso Pustoko Mangkunegaran.

"Tak Suka Isi Cerita, Ormas Bubarkan Pertunjukan wayang." 2011. http://www.wahidinstitute.org/v1/News/Detail/?id=323/hl=id/Ta 
k_Suka_Isi_Cerita_Ormas_Bubarkan_Pertunjukan_Wayang. (October 15, 2018).

Toriquddin, Moh. 2011. "Mapping Fiqh Siyasi: Islamis Versus Sekularis dan Khilafah Versus nation State." Ulul Albab: Jurnal Studi Islam 12(1): 50-66.

DOI: http://dx.doi.org/10.18860/ua.v0i0.2396

Wasino. 2014. Modernisasi di Jantung Budaya Jawa. Jakarta: Penerbit Buku Kompas.

"Wayang Dilarang, Gus Ipul: Spanduk di Islam Dulu Enggak Ada." 2017. https://www.viva.co.id/berita/nasional/873748-wayang-dilaranggus-ipul-spanduk-di-islam-dulu-enggak-ada. (October 15, 2018).

Wibowo, Prihandono. 2010. "Fenomena Neorevivalisme Islam dalam Dunia Internasional." Jurnal Global dan Strategis 4(2): 169-88.

Widyastutieningrum, Sri Rochana. 2006. Langendriyan Mangkunegaran: Pembentukan dan Perkembangan Bentuk Penyajiannya. Surakarta: ISI Press.

Wiryawan, Hari. 2011. Mangkunegoro VII $\mathcal{E}$ Awal Penyiaran Indonesia. Surakarta: LPPS. 